\title{
Diclofenac gel in the treatment of actinic keratoses
}

This article was published in the following Dove Press journal:

Therapeutics and Clinical Risk Management

14 June 201 I

Number of times this article has been viewed

\section{Christopher G Nelson \\ Department of Dermatology and Cutaneous Surgery, University of South Florida College of Medicine, Tampa, FL, USA}

Correspondence: Christopher G Nelson Department of Dermatology and Cutaneous Surgery, University of South Florida College of Medicine, I 290 I Bruce B Downs Boulevard MDC 79, Tampa, FL 33612, USA

Tel + I 8139744270

Fax + I 8139744272

Email cnelson@health.usf.edu

\begin{abstract}
Actinic keratoses are areas of intraepithelial neoplasia for which treatment is necessary. Because they arise in areas of sun damage, it is desirable to treat the entire damaged field to not only treat visible lesions, but also subclinical, emerging malignancies, ie, "field therapy", 5-fluorouracil, imiquimod, and diclofenac are all treatment options, and are discussed and compared.
\end{abstract}

Keywords: actinic keratosis, topical diclofenac, field therapy, review

\section{Introduction}

Actinic keratoses develop in fair-skinned individuals with a history of overexposure to ultraviolet light. ${ }^{1}$ Actinic keratosis is the third most common skin complaint treated by dermatologists in the US and, according to the American Academy of Dermatology, $60 \%$ of predisposed individuals over the age of 40 years have at least one lesion. ${ }^{2,3}$ They occur most frequently on sun-exposed skin of the face, scalp, arms, and hands. Important risk factors include fair skin, cumulative sun exposure, and immunosuppression, including further ultraviolet light exposure. Actinic keratosis is now considered to be the beginning of a biologic continuum that leads to invasive squamous cell carcinoma, ${ }^{1,4,5}$ thus treatment is medically necessary.

\section{Pathology and epidemiology}

Clinically, actinic keratoses present as erythematous keratotic macules, papules, and plaques. Most patients have multiple lesions, and will continue to develop new lesions from past ultraviolet-induced DNA damage, as well as cutaneous immunosuppression caused by continuing exposure. Histologically, an intraepithelial proliferation of abnormal keratinocytes is observed. When these atypical keratinocytes extend beyond the basement membrane, invasive squamous cell carcinoma is the result. Normal-appearing skin surrounding areas of actinic keratosis demonstrates molecular changes, including p53 gene mutations, and thus the whole area has the potential to develop more actinic keratoses and subsequently, squamous cell carcinoma. ${ }^{6}$ Actinic keratosis and squamous cell carcinoma share epidemiologic, cytologic, and molecular features. ${ }^{1,7,8}$ Epidemiologic data indicate that up to $10 \%$ of actinic keratosis lesions may progress to squamous cell carcinoma within 10 years, and $60 \%$ of squamous cell carcinomas arise from clinically diagnosed actinic keratoses. ${ }^{9}$ Because of the substantial risk of progression of actinic keratosis to squamous cell carcinoma and the inability to predict the behavior of individual lesions, current management 
guidelines recommend considering treatment of all actinic keratoses. ${ }^{10-13}$ The presence of field cancerization suggests that proper long-term management of actinic keratoses will require repeated treatment of continuously evolving lesions. ${ }^{14}$ Current treatments include in-office destructive therapy for individual actinic keratoses, such as cryosurgical destruction and photodynamic therapy. Patient-applied topical therapy offers treatment of a wider area affected by DNA damage and field cancerization. Actinic keratosis is a marker for an area that is at risk for development of more actinic keratoses and even squamous cell carcinoma; therefore, field treatment is recommended. ${ }^{13}$

\section{Available topical therapies}

The first field therapy to be approved was 5-fluorouracil, in 1962. Rapidly growing cells need thiamine, and putting a fluorine atom in the 5-position on a uracil molecule simulates thiamine, but when metabolized by rapidly growing cells, kills them. The result is death of actinic keratosis cells. Recent preliminary data from Stockfleth et al ${ }^{13}$ show an increase in p53 tumor suppressor gene mutations in fields treated with 5-fluorouracil (Pers comm; Stockfleth, 2011). In two studies, facial actinic keratoses treated with 5-fluorouracil twice daily for four weeks showed $100 \%$ clearance in $43 \%$ and $47.6 \%$ of patients after treatment. ${ }^{15,16}$ Sequelae of treatment with topical 5-fluorouracil include erythema, crusting, oozing, burning, and pain, which may sometimes be severe.

Imiquimod 5\% was first approved as a treatment for external genital warts in 1997. It is an immune response modifier and cytokine inducer. Imiquimod upregulates cellmediated immunity, which is effective against viruses and tumors, and has been approved for treating actinic keratoses and superficial basal cell carcinoma. Four weeks after treating facial actinic keratoses twice a week for 16 weeks, the $100 \%$ clearance rate was $44 \%-46 \% .{ }^{17}$ Recently, imiquimod $3.75 \%$ was approved in the US for treating actinic keratosis of the face and scalp using a simplified daily dosing regimen (two weeks on, two weeks off, two weeks on) with similar efficacy to imiquimod 5\% used twice a week for 16 weeks, and lower efficacy than imiquimod used three times weekly for 16 weeks. ${ }^{18}$ Side effects include skin irritation, which is dependent on dose and the immune status of the patient, and flu-like symptoms (fever, chills, aches, and pains). These sequelae are caused by increased levels of interferon, are more common with the 5\% formulation, and increase with increased frequency of use and larger area of application.

Diclofenac is a nonsteroidal anti-inflammatory drug (NSAID). Its proposed mechanism of action in treating actinic keratoses is blocking cyclo-oxygenase-2 (COX-2), thereby reducing angiogenesis and cellular proliferation. Recently, topical diclofenac has been shown to upregulate apoptosis. Induction of apoptosis appears to be highly characteristic of the mode of action of diclofenac in hyaluronic acid, and the therapeutic effect may be related to sensitization of neoplastic keratinocytes for death ligand-induced apoptosis. ${ }^{19}$ Thus, it is believed that diclofenac starves out the dysplastic keratinocytes while causing programmed cell death, which results in lesion clearance with a minimum of inflammation. Diclofenac 3\% + hyaluronic acid 2.5\% $\left(\right.$ Solaraze $\left.^{\mathrm{TM}}\right)$ is used twice a day for up to 90 days. Four weeks after 60 days of treatment, $100 \%$ of actinic keratoses were cleared in $33 \%$ of patients and, after 90 days of treatment, the $100 \%$ clearance rate was $50 \%{ }^{20} \mathrm{~A}$ recent study has demonstrated that 180 days of therapy with diclofenac shows no significant improvement over 90 days. ${ }^{21}$ A one-year extension study was performed that showed a further decrease in target (original) actinic keratoses from $90 \%$ to $95 \%$ after a year, although the cumulative actinic keratosis count had increased slightly as a result of new actinic keratoses developing in areas of field cancerization. ${ }^{22}$ Figure 1 demonstrates the steady decrease in the number of actinic keratoses over 90 days of treatment, and the further decrease 30 days and one year after completion of the 90-day course. Topical diclofenac + hyaluronic acid has been shown to be a safe and effective for treatment of actinic keratosis on the mucosal lip, with a minimum of irritation. In most cases, this consists of mild crusting, while the actinic keratoses are resolving. Patient satisfaction with this treatment is rated to be high. ${ }^{23}$ Diclofenac has been shown to be safe and effective in organ transplant recipients. Ulrich et al followed a group of 24 organ transplant patients for two years. In the active treatment group, none developed invasive squamous cell carcinoma. ${ }^{24}$

Adverse events with topical diclofenac include application site reactions, itching, erythema, dry skin, exfoliation, localized edema, paresthesia, and less frequently, photosensitivity (Solaraze package insert). The cutaneous reactions have been investigated, and are often patch test-negative. ${ }^{25-27}$ These researchers postulate a subset of actinic keratosis and skin cancer patients that are highly or at least more susceptible to local reactions caused by $\mathrm{COX}-2$ inhibitors and peroxisome proliferator-activated receptor agonists. ${ }^{28}$ They speculate that underlying molecular differences exist in these patients that make the skin more susceptible to COX-2 inhibitors. Although rare, both photocontact and allergic contact dermatitis has been reported. ${ }^{29}$ In two patients who developed maculopapular eruptions 48 and 72 hours after initiation of 


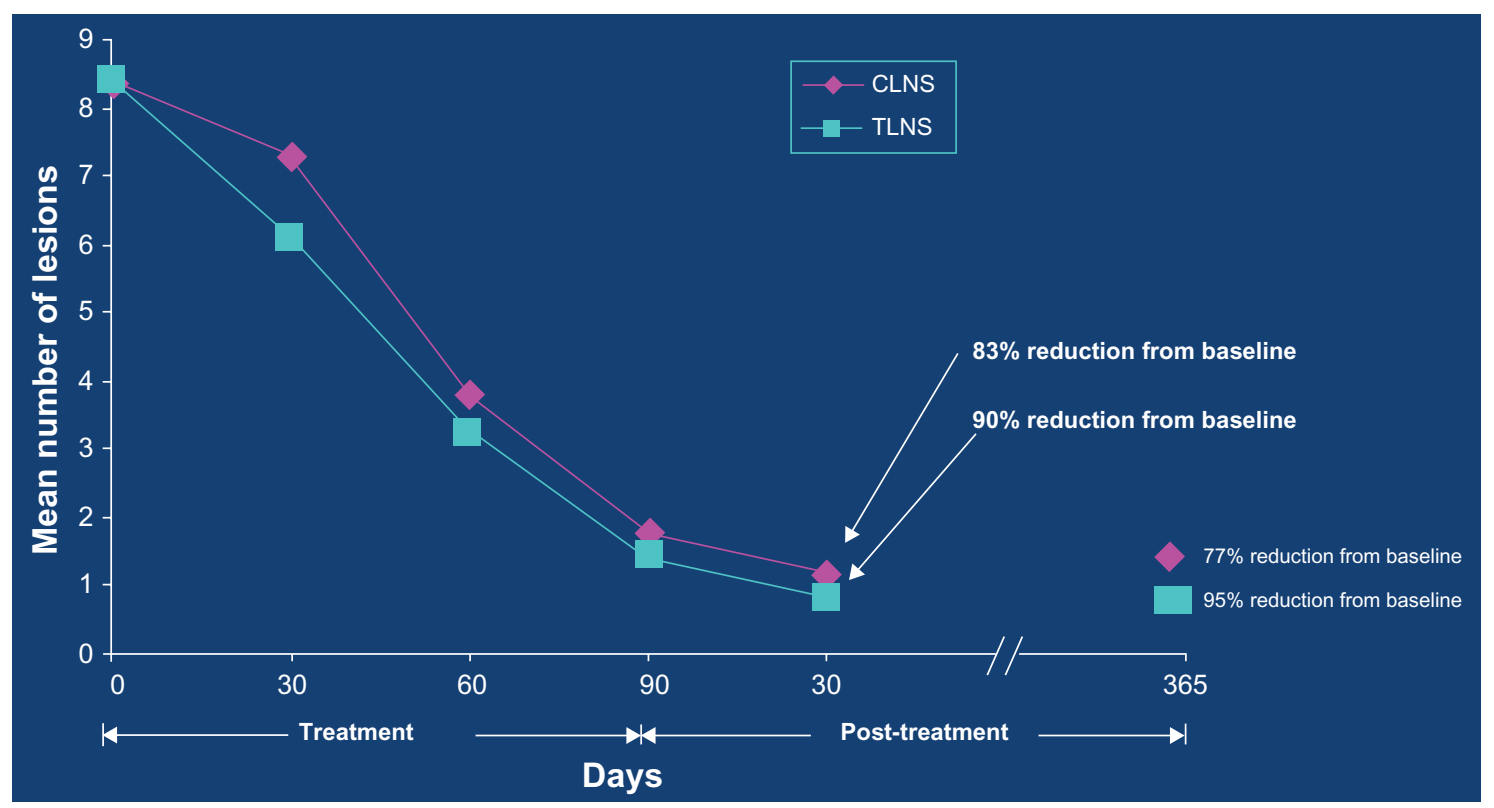

Figure I Reduction in actinic keratosis (AK) lesions over time. ${ }^{22}$

Nelson C, Rigel D; Long term Follow-up of Diclofenac Sodium 3\% in 2\% Hyaluronic Acid Gel for Actinic Keratoses: One-Year Evaluation. J Clin Aesthet Dermatol. 2009;2(7):20-25. Copyright @ 2009 Matrix Medical Communications. All rights reserved.

Abbreviations: CLNS, cumulative lesion number score; TLNS, target lesion number score.

treatment with diclofenac + hyaluronic acid, prick and intradermal tests were negative at 20 minutes, but 24 hours later an erythematous infiltrate had appeared at the intradermal test site..$^{30}$ These researchers suggested intradermal and patch tests as an indicator to diagnose reactions of this type.

The question of systemic absorption of diclofenac + hyaluronic acid gel has been raised. A series of four cases of upper gastrointestinal bleeding were reported with topical Voltaren ${ }^{\mathrm{TM}}$ gel, a formulation of diclofenac made to penetrate deeper (two were using it for backache, which was ultimately found to be caused by peptic ulcer disease). ${ }^{31}$ Solaraze, on the other hand, is in a hyaluronic acid vehicle which is designed to keep the drug in the epidermis and superficial dermis in order to optimize it for treatment of actinic keratosis. Therefore, the two products are not bioequivalent.

In 60 patients with actinic keratoses enrolled in clinical trials of Solaraze, mean serum diclofenac levels were $\leq 20 \mu \mathrm{L} / \mathrm{L}$ at the end of treatment. ${ }^{32}$ In patients with compromised skin (mainly atopic dermatitis and other dermatitic conditions), approximately $10 \%$ of the drug contained in a $2 \mathrm{~g}$ dose of the gel was absorbed systemically in both normal and compromised epidermis after application four times a day over seven days to a $100 \mathrm{~cm}^{2}$ area. ${ }^{32}$ Similarly, the drug was detected in the serum of healthy volunteers after applying the gel to the calf at a dosage of $2 \mathrm{~g}$ three times a day for six days. ${ }^{32}$ Mean peak plasma concentration, area under the curve (AUC), and time to peak plasma concentration were $4 \mu \mathrm{g} / \mathrm{L}, 9 \mu \mathrm{g} / \mathrm{L} \cdot \mathrm{h} / \mathrm{L}$, and 4.5 hours, respectively, after topical application. It should be noted that the recommended dose of Solaraze is twice daily, not three or four times daily. In contrast, an AUC of $1600 \mu \mathrm{g} \cdot \mathrm{h} / \mathrm{L}$ was obtained after administration of a single $75 \mathrm{mg}$ oral dose of diclofenac, confirming that the systemic bioavailability of the drug is considerably lower after topical application of diclofenac + hyaluronic acid gel than systemic administration of diclofenac. ${ }^{32}$ More absorption studies need to be done on patients using diclofenac + hyaluronic acid at the recommended doses in actual clinical settings.

Topical diclofenac alone and concomitant use of sunscreens has been shown not to induce photosensitivity or phototoxicity ${ }^{33}$ but because such events have been reported, patients should be cautioned to avoid sun exposure.

\section{Future development of topical treatment}

Several promising new topicals are in various stages of development. Ingenol mebutate gel (formerly PEP005) is a diterpene ester extracted and purified from the Euphorbia peplus plant. It is being evaluated for the treatment of actinic keratosis. Phase II studies have suggested that a $0.05 \%$ concentration is optimal for sites other than the face and scalp, and lower concentrations are needed for sites on the head. ${ }^{34-38}$ Treatment is once daily for two or three consecutive days, and clearance rates are higher for higher concentrations and three-day dosing. Optimal regimens have yet to be 
determined. Side effects include erythema, scaling, scabbing, itching, and burning, and are dose-related. Other novel topical treatments under investigation include sulindac + hydrogen peroxide, oleogel-S-10, and nicotinic acid.

\section{Discussion}

Clearance rates for all of the available topical field treatments for actinic keratosis are comparable. A bilateral comparison ("split face") study was conducted to assess the efficacy and tolerability of Solaraze twice daily for 90 days compared with 5 -fluorouracil 5\% twice daily for 28 days in 30 patients with actinic keratoses of the face and scalp. The diclofenac gel and 5-fluorouracil cream each demonstrated substantial and comparable efficacy in the number of lesions cleared and the number of patients with significant clearing. In fact, there was no statistically significant difference between the two products. Diclofenac induced only mild signs of inflammation compared with 5-flurouracil, despite a longer treatment period. A greater number of patients expressed satisfaction with diclofenac + hyaluronic acid gel compared with the 5-fluorouracil cream. ${ }^{39}$

Imiquimod is supplied in sachets, so much smaller quantities are available, and clearance rates are much lower and the incidence of adverse events higher for nonfacial sites. ${ }^{40}$ Solaraze is supplied in a $100 \mathrm{~g}$ tube, which makes it ideal for use on larger areas of skin, and for completion of the 90-day course of treatment. Compliance can be increased by explaining to the patient that this medication works by "starving out" the actinic keratoses, so it requires longer to work, but the trade-off is that they will have much less irritation.

A cost effectiveness model was developed for the Italian health care system, in which diclofenac + hyaluronic acid, imiquimod 5\%, and methylaminolevulanate + photodynamic therapy were compared. 5-Fluorouracil is not available in Italy. ${ }^{41}$ Based on this cost-effectiveness model, 3\% diclofenac + hyaluronic acid is considered the treatment of choice in the Italian health care system.

Solaraze has also proven effective in combination therapy regimens. In a large multicenter study of 521 patients, topical diclofenac + hyaluronic acid was used following cryosurgery, and significantly improved the clearance rate, ie, 100\% clearance of target plus cumulative lesions in $46 \%$ of patients, as opposed to $21 \%$ with cryosurgery alone. ${ }^{41}$

\section{Conclusion}

In 1985, John Knox proposed the four "Cs" for the treatment of basal cell carcinoma, and with today's increased number of options, these apply to actinic keratosis treatment as well, ie, convenience, cost-effectiveness, cure rate, and cosmetic result. Moreover, a fifth "C" can now be added, ie, compliance. Given the favorable safety profile and low rate of irritation with diclofenac, patients are more likely not only to complete their course of therapy, but be willing to use it again when necessary. Solaraze should be considered firstline for field therapy of actinic keratosis.

\section{Disclosure}

The author serves as a consultant for Graceway Pharmaceuticals, Inc and Pharmaderm, a division of Nycomed US. Otherwise the author reports no conflicts of interest in this work.

\section{References}

1. Salasche SJ. Epidemiology of actinic keratoses and squamous cell carcinoma. J Am Acad Dermatol. 2000;42(1 Pt 2):4-7.

2. Feldman, Fleischer AB Jr, McConnell C. Most common dermatologic problems identified by internists; 1990-1994. Arch Intern Med. 1998;158(7):726-730.

3. Frost CA, Green AC. Epidemiology of solar keratoses. Br J Dermatol. 1994;131(4):455-464.

4. Moy RL. Clinical presentation of actinic keratoses and squamous cell carcinoma. J Am Acad Dermatol. 2000;42(1 Pt 2):8-10.

5. Ackerman AB, Mones JM. Solar (actinic) keratosis is squamous cell carcinoma. Br J Dermatol. 2006;155(1):9-22.

6. Quatresooz PC, Pierard-Franchimont C, Pauquet P, et al. Crossroads between actinic keratosis and squamous cell carcinoma, and novel pharmacological issues. Eur J Dermatol. 2008;18(1):6-10.

7. Oppel T, Korting HC. Actinic keratosis: The key event in the evolution from photoaged skin to squamous cell carcinoma. Therapy based on pathogenetic and clinical aspects. Skin Pharmacol Physiol. 2004; 17(2):67-76.

8. Schwartz RA. The actinic keratosis. A perspective and update. Dermatol Surg. 1997;23(11):1009-1019.

9. Marks R, Rennie G, Selwood TS. Malignant transformation of solar keratoses to squamous cell carcinoma. Lancet. 1988;1(8589):795-797.

10. Glogau RG. The risk of progression to invasive disease. $J$ Am Acad Dermatol. 2000;42(1 Pt 2):23-24.

11. Callen JP, Bickers DR, Moy RL. Actinic keratoses. J Am Acad Dermatol. 1997;36(4):650-653.

12. Dinehart SM. The treatment of actinic keratoses. J Am Acad Dermatol. 2000;42(1 Pt 2):25-28.

13. Stockfleth E, Ferrandiz C, Grob JJ, et al. Development of a treatment algorithm for actinic keratoses: A European consensus. Eur J Dermatol. 2008;18(6):651-659.

14. Vatve M, Ortonne JP, Birch-Machin MA, Gupta G. Management of field change in actinic keratosis. Br J Dermatol. 2007;157 Suppl 2:21-24.

15. Loven K, Stein L, Furst K, Levy S. Evaluation of the efficacy and tolerability of $0.5 \%$ fluorouracil cream and $5 \%$ fluorouracil cream applied to each side of the face in patients with actinic keratosis. Clin Ther. 2002;24(6):990-1000.

16. Jorizzo JL, Carney PS, Ko WT, Robins P, Weinkle SH, Werschler WP. Fluorouracil $5 \%$ and $0.5 \%$ creams for the treatment of actinic keratosis: Equivalent efficacy with a lower concentration and more convenient dosing schedule. Cutis. 2004;74(6 Suppl):18-23.

17. Aldara [Package insert]. Bristol, TN: Graceway Pharmaceuticals; 2009.

18. Quist SR, Gollnick HP. Imiquimod 3.75\% cream (Zyclara) for the treatment of actinic keratoses. Expert Opin Pharmacother. 2011;12(3): 451-461. 
19. Feckler L, Stockfleth E, Braun FK, et al. Enhanced death ligandinduced apoptosis in cutaneous SCC cells by treatment with diclofenac/ hyaluronic acid correlates with downregulation of c-FLIP. J Invest Dermatol. 2010;130(8):2098-2109.

20. Wolf JE, Taylor JR, Tschen E, Kang S. Topical 3.0\% diclofenac in $2.5 \%$ hyaluronan gel in the treatment of actinic keratoses. Int $J$ Dermatol. 2001;40(11):709-713.

21. Pfleugfelder A, Welter AK, Leiter U, et al. Open label randomized study Comparing 3 months vs 6 months treatment of actinic keratoses with 3\% Diclofenac in $2.5 \%$ hyaluronic gel: a trial of the German Dermatologic Cooperative Oncology Group. J Eur Acad Dermatol Venereol. 2011 Mar 18. Doi:10.1111/j.1468-3083.2011.04005.x. [Epub ahead of print].

22. Nelson C, Rigel D. Long-term follow-up of diclofenac sodium $3 \%$ in $2.5 \%$ hyaluronic acid gel for actinic keratosis: 1 -year evaluation. J Clin Aesthet Dermatol. 2009;2(7):20-25.

23. Nelson CG, Spencer J, Nelson CG Jr. A single-arm, open-label efficacy and tolerability study of diclofenac sodium 3\% gel for the treatment of actinic keratosis of the upper and lower lip. J Drugs Dermatol. 2007; 6(7):712-717.

24. Ulrich C, Johannsen A, Röwert-Huber J, Ulrich M, Sterry W, Stockfleth E Results of a randomized, placebo-controlled safety and efficacy study of topical 3\% diclofenac gel in organ transplant patients with multiple actinic keratoses. Eur J Dermatol. 2010;20(4):482-488.

25. Montoro J, Rodriguez M, Diaz M, Bertomeu F. Photoallergic contact dermatitis due to diclofenac. Contact Dermatitis. 2003;48(2):115.

26. Kerr OA, Kavanagh G, Horn H. Allergic contact dermatitis from topical diclofenac in Solaraze gel. Contact Dermatitis. 2002;47(3):175.

27. Ueda K, Higashi N, Kume A, Ikushima-Fujimoto M, Ogiwara S. Allergic contact dermatitis due to diclofenac and indomethacin. Contact Dermatitis. 1998;39(6):323.

28. Patel MJ, Ulrich C, Forschner T. Genetically determined susceptibility to COX-2 inhibitors: A report of exaggerated responders to diclofenac $3 \%$ gel in the treatment of actinic keratoses. Br J Dermatol. 2007; 156 Suppl 3:57-61.

29. Romano A, Quaratino D, Papa G, Di Fonso M, Artesani MC, Venuti A. Delayed hypersensitivity to diclofenac: A report on two cases. Ann Allergy Asthma Immunol. 1998;81(4):373-375.

30. Zimmerman J, Siguencia J, Tsvang E. Upper gastrointestinal hemorrhage associated with cutaneous application of diclofenac gel. Am J Gastroenterol. 1995;90(11):2032-2034.

31. Jarvis B, Figget DP. Topical 3\% diclofenac in $2.5 \%$ hyaluronic gel: A review of its use in patients with actinic keratoses. Am J Clin Dermatol. 2003;4(3):203-213.
32. Ortonne JP, Queille-Roussel C, Duteil L. 3\% diclofenac in 2.5\% hyaluronic acid (Solaraze) does not induce photosensitivity or phototoxicity alone or in combination with sunscreens. Eur J Dermatol. 2006;16(4):385-390.

33. Siller G, Gebauer K, Welburn P, Katsamas J, Ogbourne SM. PEP005 (ingenol mebutate) gel, a novel agent for the treatment of actinic keratosis: Results of a randomized, double blind, vehicle-controlled multicentre, Phase IIa study. Australas J Dermatol. 2009;50(1):16-22.

34. Ulrich M, Drecoll U, Stockfleth E. Emerging drugs for actinic keratoses. Expert Opin Emerg Drugs. 2010;15(4):545-555.

35. Spencer J. Multicenter, randomized double blind, vehicle controlled, dose ranging study to evaluate the efficacy and safety of PEP005 (ingenol mebutate) gel, $0.05 \%, 0.01 \%$, and $0.015 \%$ when used to treat actinic keratoses (AK) on the head. Poster 2913, presented at the 60 th annual meeting of the American Academy of Dermatology, New Orleans, LA; February 4-8, 2011.

36. Schmeider G. Multicenter, open-label, dose-area escalation cohort study to evaluate the safety of PEP005 (ingenol mebutate) gel, $0.05 \%$ applied for two consecutive days to treatment areas of up to $100 \mathrm{~cm}^{2}$ in patients with actinic keratoses (AK) on the extensor (dorsal aspect) forearms(s). Poster 2915, presented at the 60th annual meeting of the American Academy of Dermatology, New Orleans, LA; February 4-8, 2011.

37. Swanson N. Multicenter, randomized, parallel-group, double-blind, vehicle-controlled study to evaluate the efficacy and safety of PEP005 (ingenol mebutate) gel, $0.05 \%$ in patients with actinic keratoses (AKO on non-head locations. Poster 105, presented at the 60th annual meeting of the American Academy of Dermatology, New Orleans, LA; February 4-8, 2011.

38. Smith SR, Morhenn VB, Piacquadio GJ. Bilateral comparison of the 3\% diclofenac gel and 5\% 5-fluorouracil cream in the treatment of actinic keratosis of the face and scalp. J Drugs Dermatol. 2006; 5(2):156-159.

39. Gebauer K, Shumack S, Cowen PS. Effect of dosing frequency on the safety and efficacy of imiquimod 5\% cream for the treatment of actinic keratosis of the forearms and hands: A phase II randomized placebocontrolled trial. Br J Dermatol. 2009;161(4):897-903.

40. Colombo GL, Chimenti S, Di Matteo S et al. Cost-effectiveness analysis of topical treatments for actinic keratosis in the perspective of the Italian health care system. G Ital Dermatol Venereol. 2010;145(5):573-581.

41. Berlin JM, Rigel DS. Diclofenac sodium 3\% gel in the treatment of actinic keratoses. J Drugs Dermatol. 2008;7(7):669-673.
Therapeutics and Clinical Risk Management

\section{Publish your work in this journal}

Therapeutics and Clinical Risk Management is an international, peerreviewed journal of clinical therapeutics and risk management, focusing on concise rapid reporting of clinical studies in all therapeutic areas, outcomes, safety, and programs for the effective, safe, and sustained use of medicines. This journal is indexed on PubMed Central, CAS,

\section{Dovepress}

EMBase, Scopus and the Elsevier Bibliographic databases. The manuscript management system is completely online and includes a very quick and fair peer-review system, which is all easy to use. Visit http://www.dovepress.com/testimonials.php to read real quotes from published authors. 